\title{
Entrepreneurial Logistics Education in Institutions of Higher Learning: The Case of Universiti Malaysia Kelantan
}

\author{
Razman Hafifi Redzuan ${ }^{1}$, Mohamed Dahlan Ibrahim ${ }^{1} \&$ Muhammad Zaly Shah Muhammad Hussein ${ }^{2}$ \\ ${ }^{1}$ Faculty of Entrepreneurship \& Business, Universiti Malaysia Kelantan, Malaysia \\ ${ }^{2}$ Faculty of Built Environment, Universiti Teknologi Malaysia, Malaysia \\ Correspondence: Razman Hafifi Redzuan, Faculty of Entrepreneurship \& Business, Universiti Malaysia Kelantan, \\ Malaysia.
}

Received: May 1, 2019

Accepted: June 1, 2019

Online Published: July 7, 2019

doi:10.5430/rwe.v10n2p58

URL: https://doi.org/10.5430/rwe.v10n2p58

\begin{abstract}
In recent times, the unemployment rate has been reported increasing as year passes as well as the nation's economy been fluctuating (Department of Statistics Malaysia, 2016). Besides that, from the survey, it has been noted that students that eager to step into entrepreneurship field were insufficient to cope up with nation's Gross Domestic Product (GDP). Therefore, the main objective of the research is to determine the number of logistics students possesses entrepreneurship personality. In addition, to identify whether the program offered could shift the mindset of logistics students become an entrepreneur as well as to provide suggestion to UMK in order to sustain the logistics program, survey was done in Universiti Malaysia Kelantan (UMK) City Campus, where 123 respondents were chosen out of 180 fourth year logistics students referring to Krejcie and Morgan table. Convenience sampling has been used to determine the sample size. The data was collected using a quantitative method where the questionnaires were designed using Holland Test Occupational Theme Model. Descriptive analyses were conducted to analyze the data obtained. From the finding, it's proven that majority of logistics students are interested in becoming an entrepreneur as well as the entrepreneurial education offered by UMK is fitted in instilling plus producing more entrepreneur undergraduates especially in Logistics and Distributive Trade program.
\end{abstract}

Keywords: entrepreneurial logistics education, higher learning, Universiti Malaysia Kelantan, Malaysia

\section{Introduction}

According to the Department of Statistics Malaysia, the recent unemployment rate in Malaysia is 3.20 per cent in the fourth quarter of 2015 and aroused about 3.40 per cent earlier 2016. Most of the people in current trends would prefer working under companies, hence this leads to the unemployment rates to be higher every year. Thus, to cope with the economic situation as well as to reduce the unemployment rate in the country, the entrepreneurship field has been encouraged in recent times especially for fresh graduates.

Therefore, Universiti Malaysia Kelantan (UMK) known as one of the public institutions that offer entrepreneurial studies to students, where the main aim of the university is to generate students to become entrepreneurs. Besides, the percentage of university student who eager to step into self-employment is small (Franco, Haase, \& Lautenschlager, 2010; Osman \& Sentosa 2013; Orji, et.al 2018). In addition, according to Department of Students Affairs and Alumni (HEPA) UMK, the number of students who indulge themselves as entrepreneur was 37.99\%, which was insufficient to cope up with the nation's GDP. Thus, the main aim of the research is to determine the number of logistics students which possess entrepreneurship personality by using Holland Test Occupational Theme Model.

\section{Literature Review}

To support the vision of Malaysia; towards high-income country, UMK has making evolution in thriving the human capital to help the country's development. Based on the motto of UMK; Entrepreneurship is Our Thrust; the strategies in upholding entrepreneurship education would be worthless without efficient and effective staff. Prof. Dato' Dr. Mortaza Bin Mohamed, as Vice Chancellor, head of the university together with academics prepared UMK to become a reliable institution of higher learning in providing programmes of high quality that meet the demand of 
market. UMK offers twenty-five programmes at five different faculties in three campuses which are in Pengkalan Chepa, Bachok, and Jeli in conjunction with the recent development of the industry.

Besides that, UMK is an institution that focuses on entrepreneurship program to improve student and to provide enterprise information and abilities acquisition. UMK developed a dynamic part in outlining business enterprise programs for the undergraduates. These parts incorporate giving physical abilities and advances to students to begin their own particular business, systems administration, and enterprise preparing (Al Mamun, Nawi, \& Shamsudin, 2016; Onyinye, Jonathan \& Emmanuel 2018). UMK offers 12 credits of entrepreneurial courses over the faculties which is at least $10 \%$ of the program material's built up learning in business training that consolidates the truth experiences and also contextual examples of achievement stories shared by successful business people. UMK provides numerous projects, for example, the Students in Enterprise Program (SIEP) and the Social Entrepreneurship Program where the students will end up taking an interest in a program for economic and community advancement. This is directed through a social business enterprise subject (Al Mamun et al., 2016; Perera, Johnson \& Hewege 2018). Hence, in conducting the research, Holland Test Occupational Theme was used to test the personality entrepreneurial students. In the model, it consists of six basic types of work environments, which are Realistic, Investigative, and Artistic, Social, Enterprising and Conventional (see Table 1).

Table 1. Holland test occupational theme

\begin{tabular}{ll}
\hline $\begin{array}{l}\text { Type of } \\
\text { Personalities }\end{array}$ & Characteristics \\
\hline Realistic & $\begin{array}{l}\text { A person with the Realistic personality type would have athletic or mechanical } \\
\text { capacities. This type of personality reflects someone that likes to work with } \\
\text { objects, machines, plants, or animals, or to be outdoors (Crowder and Clark, } \\
\text { 2016). }\end{array}$ \\
\hline Investigative & $\begin{array}{l}\text { A person with the Investigative personality type would reflect someone that is } \\
\text { analytical, technical, and scientific (Crowder \& Clark, 2016). }\end{array}$ \\
\hline Artistic & $\begin{array}{l}\text { Artistic can defines as people who have artistic, innovating or intuitional abilities } \\
\text { and like to work in unstructured situation using their imaginational and creativity } \\
\text { (Hargreaves, Boyle, and Harris, 2014) }\end{array}$ \\
\hline Enterprising & $\begin{array}{l}\text { Individuals that want to be a successful entrepreneur should be social able with } \\
\text { others to easy in doing in their business like they must create a social network with } \\
\text { others people (Ktoridou, Epaminonda, Arola, Kyprianides, \& Paschalis, 2013) }\end{array}$ \\
\hline Enterprise personality people possess characteristics such as energetic, ambitious, \\
adventurous, sociable and \\
self-confidence (Ktoridou, Epaminonda, Arola, Kyprianides, \& Paschalis, 2013).
\end{tabular}

\section{Research Methodology}

The quantitative method has been used to gather the required data where all the essential data for the research were obtained by using Holland Test Occupational Theme model. 123 fourth year logistics students were chosen by using convenience sampling out 180 students. These numbers of respondents were obtained by using Krejcie and Morgan table. Primary and secondary data has been used to collect the information. Questionnaires distributed to the focus population in order to obtain data as a primary data (Osabohien, et al. 2018). It consisted of two sections of questions, where Section A covers the demographic information of the respondents while section B covered questions regarding the Holland Test Occupational Theme Model. In addition, secondary data also had been used to support the research, where it includes results of previous research as well as data from Faculty Entrepreneurship and Business (FKP) and Department of Students Affairs and Alumni (HEPA), UMK. 
Several methods have been used in order to identify whether students personality are more to entrepreneurship attributes as highlighted in Holland Test Model. One of the common methods would be descriptive analysis. However, in the study, the appropriate model being used is Holland Occupational Theme Model.

\section{Data Analysis and Findings}

Holland Occupational Theme or also known as Self Directed Search (SDS) been used to conduct the research. The SDS question was developed by Dr. John Holland and there are 192 questions to help categorize individuals into six distinct types of personalities. In conjunction with that, descriptive analysis was used in analyzing data in number of different ways. By using descriptive analysis, the research would derive means of the six personalities which are realistic, investigative, artistic, social, enterprising and conventional. These scales are used as independent variables.

Table 2. Descriptive statistics

\begin{tabular}{lll}
\hline & Mean & N \\
\hline Sum. Realistic & 7.23 & 123 \\
Sum. Investigative & 9.63 & 123 \\
Sum. Artistic & 12.42 & 123 \\
Sum. Social & 18.37 & 123 \\
Sum. Enterprising & 12.97 & 123 \\
Sum. Conventional & 15.30 & 123 \\
\hline
\end{tabular}

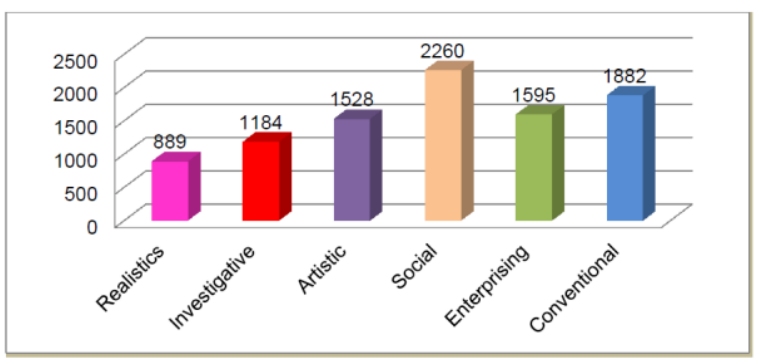

Figure 2. Frequency of personalities

Table 2 above illustrates the number of respondents and mean of independent variables. According to the data above, average of six type personalities, Social possesses the highest mean which is 18.37. It illustrates that majority of fourth year logistics students in UMK are more to social personality. The sequence followed by the Conventional 15.30, Enterprising 12.97, Artistic 12.42, Investigative 9.63 and Realistic 7.23 personalities. The three highest personalities were chosen which are Social, Conventional and Enterprising in order to determine whether students possess entrepreneurial attributes.

Meanwhile, based on the Figure 2 above, most students are tending to Social personality, which is 2260 answer for "yes". This shows that 123 respondents from Logistics course have chosen the items that they are interest to do which are related to the personality of entrepreneurs. Second higher among the personality is Conventional; the frequency of conventional is 1882 times. Third high is Enterprising, the respondents have chosen the item represent on enterprising personality is 1595 times. According to John L. Holland, the three main highest personalities are interrelated with each other and as well as possesses the entrepreneurship features.

\section{Conclusion and Recommendation}

The main significant aim of the study was to determine whether fourth year logistics student possess entrepreneurial attribute, to identify whether the program offered; Bachelor of Entrepreneurship (Logistics and Distributive Trade) could lead logistics students to be logistics entrepreneur as well as to provide the best suggestion to UMK in order to sustain the logistics program. Overall, the result indicated that three highest personalities' affects students' mindset to become entrepreneurs, which are Social, Conventional and Enterprising personality. Therefore, it could be 
expected that, these foremost personalities are essential to logistics students to instill entrepreneurial attributes in them.

However, the enterprising attributes is not the highest personality of students, hence UMK should provide more entrepreneurship knowledge through practical learning rather than theoretical learning such as involving students into business environment or practices. Practical learning would be a platform for students to gain more experience and skills. Moreover, UMK can collaborate with several logistics company to give the chance for students to work at their company which enable them to observe the operation process. Thus, students could earn ample of knowledge and information on handling business.

It is also recommended that UMK should create entrepreneurship contests as a compulsory activity for students. By this kind of activity, students will volunteer themselves to take part. This is because; students would prefer to actively join in outdoor activities rather than indoor learning. Besides that, it also helps students get more exposure than classroom learning. Last but not least, university can work together with SME Corporation Malaysia to provide students with information about start-up a business in term of obtaining financial assistance, market access, infrastructure activities and other support programs. However, the research is not a perfect study although the study has reached the aims. There were still had several limitations in the study. First is the time limitation. The time frame of the research was too short. Most of the research study taking about two years to complete their study. Second, the population of the questionnaire survey is small; the questionnaire survey was conducted only in Universiti Malaysia Kelantan students from the seventh semester who pursuing Bachelor of Entrepreneurship (Logistics and Distributive Trade) course.

\section{References}

Al Mamun, A., Nawi, N. B. C., \& Shamsudin, S. F. F. B. (2016). Examining the Effects of Entrepreneurial Competencies on Students' Entrepreneurial Intention. Mediterranean Journal of Social Sciences, 7(2), 119. https://doi.org/10.5901/mjss.2016.v7n2p119

Crowder, C. L., \& Clark, A. (2016). Career Exploration Model for Students in Human Resource Development.

Department of Statistics Malaysia, (2016). Malaysia Unemployment Rate. Retrieved from http://www.tradingeconomics.com/malaysia/unemployment-rate

Department of Statistics Malaysia. (2016). Malaysia Gross Domestic Product (GDP) Growth Rate. Retrieved from http://www.tradingeconomics.com/malaysia/gdp-growth

Franco, M., Haase, H., \& Lautenschläger, A. (2010). Students' entrepreneurial intentions: an inter-regional comparison. Education + Training, 52(4), 260-275. https://doi.org/10.1108/00400911011050945

Hargreaves, A., Boyle, A., \& Harris, A. (2014). Uplifting Leadership. San Francisco: Jossey-Bass.

Holland, J. L. (1997). Making vocational choices: A theory of vocational personalities and work environments. Psychological Assessment Resources.

Ktoridou, D., Epaminonda, E., Arola, N. A., Kyprianides, G., \& Paschalis, A. (2013). The Fit Between Major of Study and Personality Type: An Application of Holland's Codes in Cyprus.

Onyinye, I., Jonathan, E., \& Emmanuel, O. (2018). Foreign Capital Inflows and Unemployment in Nigeria: A New Evidence from ARDL-Bounds Testing Approach. International Journal of Business, 5(6), 176-188. https://doi.org/10.18488/journal.62.2018.56.176.188

Orji, A., Ogbuabor, J. E., Okon, A. N., \& Anthony-Orji, O. I. (2018). Electronic Banking Innovations and Selected Banks Performance in Nigeria. The Economics and Finance Letters, 5(2), 46-57. https://doi.org/10.18488/journal.29.2018.52.46.57

Osabohien, R., Osuma, G., Ndigwe, C., \& Ozordi, E. (2018). Social Protection and Agricultural Production In Ecowas: The Youth Unemployment Question. Journal of Social Economics Research, 5(2), 51-62. https://doi.org/10.18488/journal.35.2018.52.51.62

Osman, Z., \& Sentosa, I. (2013). Mediating effect of customer satisfaction on service quality and customer loyalty relationship in Malaysian rural tourism. International Journal of Economics Business and Management Studies, 2(1), 25-37.

Perera, C. R., Johnson, L. W., \& Hewege, C. R. (2018). A review of organic food consumption from a sustainability perspective and future research directions. International Journal of Management and Sustainability, 7(4), 204-214. https://doi.org/10.18488/journal.11.2018.74.204.214 